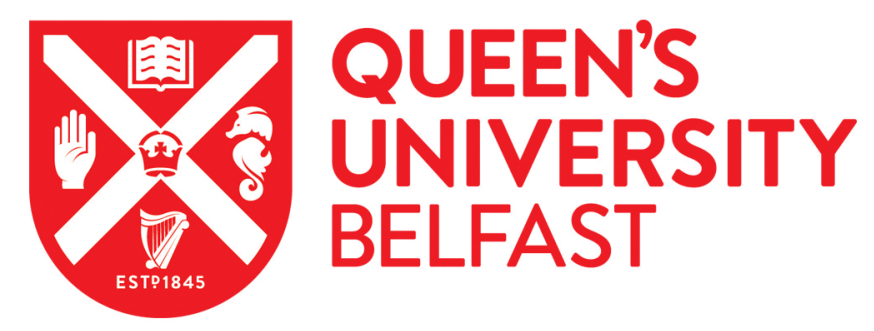

\title{
Collective Action in SCM: A call for activist research
}

Touboulic , A., \& McCarthy, L. (2019). Collective Action in SCM: A call for activist research. International Journal of Logistics Management . https://doi.org/10.1108/IJLM-08-2019-0222

Published in:

International Journal of Logistics Management

Document Version:

Peer reviewed version

Queen's University Belfast - Research Portal:

Link to publication record in Queen's University Belfast Research Portal

Publisher rights

(c) 2019, Emerald Publishing Limited. This work is made available online in accordance with the publisher's policies. Please refer to any applicable terms of use of the publisher.

\section{General rights}

Copyright for the publications made accessible via the Queen's University Belfast Research Portal is retained by the author(s) and / or other copyright owners and it is a condition of accessing these publications that users recognise and abide by the legal requirements associated with these rights.

Take down policy

The Research Portal is Queen's institutional repository that provides access to Queen's research output. Every effort has been made to ensure that content in the Research Portal does not infringe any person's rights, or applicable UK laws. If you discover content in the Research Portal that you believe breaches copyright or violates any law, please contact openaccess@qub.ac.uk. 


\title{
Collective action in SCM: a call for activist research
}

\author{
Anne Touboulic \\ Business School, University of Nottingham, Ningbo, China, and \\ Lucy McCarthy \\ Department of Management, \\ Queen's University Belfast, Belfast, UK
}

Received 19 August 2019

Revised 20 August 2019

Accepted 20 August 2019

\begin{abstract}
Purpose - The purpose of this paper is to explore the current focus of supply chain management (SCM) research; it considers field level and societal constraints and consequently the potential for change. It details the underlying assumptions in the field, considering the dominant paradigms and stakeholders, and how this has shaped the research we have engaged in as a community of scholars.

Design/methodology/approach - This is a reflective inquiry that seeks to deconstruct the dominant discourses and paradigms in SCM. It offers alternative avenues of inquiry to "traditional" research, considering how different questions, perspectives and approaches might yield different learning for the field. offering alternative avenues to traditional research.

Findings - This is a call for collective action, for solidarity, for a re-imagining of what research in SCM could look like. Research activism is challenging and potentially risky but necessary for the research community to engage in, particularly in light of the global societal grand challenges. Change can take place in the SCM field through collective action and solidarity. Three levels of activism are explored here - acting to solve the grand challenges, acting to change the field and acting as individuals.

Originality/value - This is a "speak-out" piece, which embraces and encourages reflexivity, new methods of doing and writing research as well as different perspectives, and especially a consideration for context and multiple players in the supply chain. The authors contend that it is urgent to re-appropriate our own agency as SCM researchers.
\end{abstract}

Keywords Sustainability, Europe, Management research, Supplier management, Narrative inquiry, Performance measurements

Paper type Viewpoint

As part of reading this paper we encourage you to listen to the song "Respire" by Mickey 3D (2016) as we feel it captures the essence of our argument.

\section{Introduction}

This essay explores the current focus of supply chain management (SCM) research, it considers field level and societal constraints and consequently the potential for change. We detail the underlying assumptions in our field, consider the dominant paradigms and stakeholders, and how this has shaped the research we engage in. We invite reflection upon the following questions: Have we become a product of our field? Are we producing and reproducing the dominant discourses, paradigms, research topics? Can we interrogate the performative nature of research? What are the main definitions, themes and discursive practices that have shaped our field? Have we embraced our silos? Could we do more? We call for reflection on our own role as researchers, our philosophy, our politics, our purpose. What is the value of our work? Do we justify our work based on its impact in the academic community alone? In its ability to attract funding or corporate interest or is it broader than that? Can we seek to change the world? If supply chains can play a central role in transitioning to more socially equitable societies (Mohrman and Worley, 2010), how can the research community encourage this transition?

Research activism does not entail disregarding or devaluing the research we have already engaged with, are currently exploring, or creating, but rather that we consider the 
purpose of our research. In line with Elie Wiesel, we consider that we must always take sides and not remain silent as claims of neutrality, and hence silence, helps oppressors. There are urgent societal challenges shaping the environment in which we are currently doing research that cannot be ignored. This is a call for collective action, for solidarity, for a reimagining of what research in SCM could look like. We believe there is a range of researcher activist dimensions that can be engaged with from the individual to the organisation and the collective levels of resistance. Whether large or small, we encourage ourselves to reflect on our positions of agency in each role we take: researcher, writer, educator, organiser, community member and colleague.

\subsection{Deconstructing the dominant discourse of SCM}

In this section we take stock of the dominant discourse that has shaped the field of logistics and SCM to outline the way in which this has constructed what is legitimate and possible to investigate (Phillips and Hardy, 2002). We specifically recognise the performative nature of discourse and its inter-relation with material practices. In this sense discourse is constitutive of the research field, creating ways of organising and conducting research (Christensen et al., 2013). Hence, the discourse, for instance in journal articles, in our field not only serves to conceptualise and theorise our field, it also contributes to the (re)production of the reality of logistics and SCM as an area of practice. In other words, the adoption of certain dominant perspectives, theories and units of analysis in logistics and SCM means research may tend to reproduce patterns of power observed in practice, and hence plays a role in maintaining dominant exploitative practices. To borrow from New (1997, p. 18), we consider that "the ideas of SCM do not merely reflect" the empirical reality but "play a role in constituting it".

As a starting point to unpack the underlying assumptions that have shaped the field of SCM, we take a look at some of the most accepted definitions of SCM that have emerged over four decades of research and what they tell us about the concept but also the practice of SCM. The definitions are presented in Table I, showing the issues and themes that are emphasised.

We note from our search for definitions over this period that there has been a movement in the late 2000s and early 2010s towards debating the nature of the discipline and the very concept of SCM. There is not so much a focus on defining SCM per se but on highlighting how the lack of consensual definition serves to assert the value of the field academically. From the above table, it is clear that SCM is conceived as a utilitarian notion, and a clinical and mechanistic view of SCM through the definitions transpires (i.e. it can be managed, controlled, it is made of different functional parts [...]). The salient themes emerging from the few well-accepted definitions, and therefore reproduced in the majority of the SCM academic literature, centre around the non-human material aspects and a narrow focus on process and performance to serve the customers (and the firm). There is limited acknowledgement of context in that no reference is made to the relational embeddedness of $\mathrm{SC}$ in broader societal, political and environmental dynamics. Much attention is dedicated to emphasising the complexity of the SC (i.e. multi-layered) and its management. This prevailing complexity discourse seems to allow for an acceptance of our lack of knowledge about SC processes and their implications, but also of our failure to actually re-organise them to address grand societal challenges.

In addition to considering definitions in how they have shaped the SCM discourse, we take stock of literature reviews produced in the field as a way to obtain a snapshot of research trends. Literature reviews sum up existing research, "identifying patterns, themes and issues", they can also aid a conceptual understanding of the field to assist in theory development (Seuring and Müller, 2008). In this way they tend to reproduce the problems and voices that are already being considered and so offer a good insight into the direction 


\begin{tabular}{|c|c|c|c|c|}
\hline Decade & Author & Definition & Salient themes & . Lonlec \\
\hline 1980s & Jones and Riley (1985) & $\begin{array}{l}\text { "Supply chain management deals with the } \\
\text { total flow of materials from suppliers through } \\
\text { end users [..." }\end{array}$ & $\begin{array}{l}\text { Flow, linear, } \\
\text { customer-driven, } \\
\text { material-centric }\end{array}$ & \\
\hline $1990 \mathrm{~s}$ & Monczka et al. (1998) & $\begin{array}{l}\text { SCM is a concept, "whose primary objective is to } \\
\text { integrate and manage the sourcing, flow, and } \\
\text { control of materials using a total systems } \\
\text { perspective across multiple functions and } \\
\text { multiple tiers of suppliers" }\end{array}$ & $\begin{array}{l}\text { Process, flow, control, } \\
\text { material-centric, } \\
\text { functional, } \\
\text { multiplicity/ } \\
\text { complexity }\end{array}$ & \\
\hline $2000 \mathrm{~s}$ & Mentzer et al. (2001) & $\begin{array}{l}\text { "The systemic, strategic coordination of the } \\
\text { traditional business functions and the tactics } \\
\text { across these business functions within a } \\
\text { particular company and across businesses within } \\
\text { the supply chain, for the purposes of improving } \\
\text { the long-term performance of the individual } \\
\text { companies and the supply chain as a whole" }\end{array}$ & $\begin{array}{l}\text { Process, functional, } \\
\text { performance-driven, } \\
\text { strategic, integrated, } \\
\text { multiplicity/ } \\
\text { complexity, relational }\end{array}$ & \\
\hline 2010s & Ellram and Cooper (2014) & $\begin{array}{l}\text { "SCM as a process, philosophy, and governance } \\
\text { structure all add value to the theoretical and } \\
\text { practical understanding and execution of } \\
\text { supply chain management. The process } \\
\text { perspective of SCM is critical to supply chain } \\
\text { efficiency, understanding and improving } \\
\text { activities involved in SCM, cross-functional and } \\
\text { interorganizational linkages, sharing } \\
\text { information, sustainability, and related issues. } \\
\text { SCM as a philosophy is critical to } \\
\text { understanding the value that SCM can add to } \\
\text { competitive advantage, and critical to internal } \\
\text { integration, focus, and cross-functional } \\
\text { understanding. It embraces the concept of } \\
\text { supply chain orientation. SCM as governance } \\
\text { considers the fundamental nature of the } \\
\text { organization in regard to what we do ourselves } \\
\text { vs outsource, how we treat others in the supply } \\
\text { chain in terms of relationship issues, and who } \\
\text { controls various aspects of SCM" }\end{array}$ & $\begin{array}{l}\text { Process, functional, } \\
\text { relational, integrated, } \\
\text { performance-driven }\end{array}$ & $\begin{array}{r}\text { Table I. } \\
\text { Definitions of SCM } \\
1980-2010\end{array}$ \\
\hline
\end{tabular}

and focus of the field. Drawing on several literature reviews from the last five years (e.g. Cerchione and Esposito, 2016; Durach et al., 2015, 2017; Wang et al., 2016; Wong et al., 2015; Wu et al., 2016; Maestrini et al., 2017; Fang and Zhang, 2018; Amui et al., 2017; Taticchi et al., 2015; Ben-Daya et al., 2019; Gelsomino et al., 2016; Govindan and Bouzon, 2018; Touboulic and Walker, 2015), we detail some of the main themes that have emerged in the field of logistics and SCM research. These are organised around three main avenues with the first two reflecting the overarching foci of the field (i.e. a-temporal) and the last one being more trend-based (i.e. temporal):

- gaining, managing and sustaining performance (efficiencies, innovation, performance measurement, dynamic organisation capabilities, capability improvements, resilience, TQM and collaboration);

- technologisation of SCM processes (big data, digital, internet of Things, industry 4.0, decision support tools and smart supply chain); and

- issues-based research (reverse logistics, cold chain, reshoring, humanitarian logistics, environmental management and supply chain finance). 
The focus of logistics and SCM research tends to be quite narrow, breaking down the complexity into individual and ideally measurable aspects, e.g., capturing the economic efficiencies from knowledge transfer to improve the management of cold chains between a buyer and a supplier.

The analysis above serves to highlight the prevailing themes and conceptualisations that shape of our field and by considering these aspects we can highlight the underlying assumptions of SCM but also its dominant voices. The narrative of SCM appears to be one of efficiency through control, measurement, performance management and rationalisation. This echoes New's (1997) argument that the supply chain ideal is constructed around the dominant logic of efficiency. This also clearly resonates with the dominant philosophical and methodological rationalist paradigm of the field, as highlighted by a number of previous authors (e.g. Darby et al., 2019; Touboulic and Walker, 2016), which values context-free, fragmented perspectives and abstract theorisation, seeking to replicate the natural sciences' controlled environments.

From this standpoint, the SCM field could be considered a big lab where researchers come in as expert-observers to pull the SC problems apart into "manageable" variables. The dominant actors and voices of these SC research problems are technology and big business with the instrumental purpose of serving constructed value focussed end-users, $i$. e., "the cult of the customer" (New, 1997, p. 17). The aspiration towards the scientific rigour, rationality and objectivity of the natural sciences is also symptomatic of the broader area of organisation studies for its gendered orientation, i.e., relying on masculine notions and culture (Phillips et al., 2014; Pullen and Rhodes, 2015). This dominant masculinity pervades our modes of inquiry, knowledge production processes, quality criteria, research questions and even forms of writing. For example, despite multiple calls for more qualitative, action and interpretive research in the fields of logistics and SCM (Näslund, 2002; Voss et al., 2002; Burgess et al., 2006; Boyer and Swink, 2008; Carter et al., 2008; Towers and Chen, 2008; Barratt et al., 2011; Kaufmann and Denk, 2011), their legitimacy still depends on their ability to fulfil prevailing rigour criteria (Shah and Corley, 2006; Eisenhardt, 1991) through "measurable constructs" and "well-developed instruments" (Eisenhardt, 1991 in Phillips et al., 2014, p. 316). This manifests in attempts to remove the softness and idiosyncrasies out of these approaches in order to make them fit the hard scientific mould.

The dominant SCM discourse has tremendous impacts on the field and we would argue that its primary consequence is to offer a predominantly sanitised masculine view of SCM in that it is decontextualised, depoliticised and dehumanised. On top of this, the current academic system reinforces conformity pressures on SCM researchers, further constructing and constraining what are deemed acceptable research agendas and practices.

In practice, organisational processes, as embodied by SCs, have been driven by increased and somewhat inescapable bureaucratisation, privileging rules, regulations and measurements over the humane and moral dimensions of organising (Cummings and Bridgman, 2011; Al-Amoudi et al., 2017). The concept of dehumanisation finds its roots in the work of sociologists and thinkers such as Marx (alienation), Weber (disenchantment) and Durkheim (deficit in social solidarity). The dehumanisation of organisational processes is associated to the idea that primacy has been given to productivity, economic efficiency and commoditisation of labour, which is not a novel realisation in itself (e.g. Aktouf, 1992). However, more attention has been paid to this idea over recent years during which we have witnessed numerous corporate scandals, several financial crises and a general mounting critique over "business as usual". The concept of dehumanisation resonates particularly true of the field of SCM, which is characterised by a lack of paradigmatic diversity resulting in the mainstreaming of a dehumanised view of supply chains. In the context of SCs, processes 
of dehumanisation translate into practices that favour technological advances, emphasise efficient use of resources, promote financial KPIs and the market ideology; and treat people as passive parts of production networks. As highlighted above, it is not solely in practice that these ideas have been perpetuated, in particular through the neo-liberal discourses of the large corporations, but also in SCM scholarship and education, which leads us to question our current frameworks.

Our field is constrained in its approaches, predominantly functionalist, and in its conceptualisations. As discussed above, more emphasis has been placed on the processes and technological/mechanical aspects rather than on the complex, embedded and human dimensions of logistics and SCM. Furthermore, as pointed out by several authors, the dominant perspective in the field remains that of large multinationals whose interests, concerns, actions and decisions constitute the primary focus of most of our research (New, 1997; Quarshie et al., 2016; McCarthy et al., 2018). Research has therefore tended to reproduce the patterns observed in practice, i.e., top-down and rationalist (Pagell and Shevchenko, 2014). Therefore, it has thus far failed to unveil the reality of practices for all players in the chain and the multiplicity of perspectives on the key challenges shaping our research. The language we use is disconnected and objective, taken from the sciences where clinical, regulated and laboratory research are the norm. Utilising their language, we tend to objectively discuss poor outcomes, citing that they were to issues outside of our "control" e.g. "due to poor visibility" or "due to the increased complexities of multi-tier supply chains". This adds to the legitimisation of imperatives such as globalisation and best practice and suggests that there is no alterative (Fournier and Grey, 1999). We distance the outcomes from the decision makers and this is particularly pertinent in globally dispersed supply chains where we outsource not only activities but the responsibility of poor labour practices, environmental disasters and resource depletion to the supplier companies. Prevalent ideas, generally accepted as positive, such as "best practice", fail to add the dimension of ownership i.e. "best practice" for whom? and thus reinforce the dominance of the main actors.

Within the realm of this research there is also an embedded expectation that theory will be applied, developed and extended in every piece of research through rationalist masculine approaches built on abstraction, objectivity and rigour. There is a particular focus on the development of new theories. Throughout the academic system (i.e. from the inception of idea, the review process, etc.), we have been socialised to think we must contribute novel theoretical insights and that work without this is less than. Whilst we acknowledge the usefulness of a good theory (Lewin, 1951), we run the risk of trapping ourselves into a "theory cave" (Bothello and Roulet, 2018) as the search for theory can distract and divert us from making a difference through our research. We also see this as a further constraint emanating from the dominant rational-masculine tradition whereby qualitative embedded work is trivialised as storytelling, anecdotal and messy (Phillips et al., 2014).

Much of this discussion concerning issues of legitimacy in the field relates to the on-going debate about the nature of research in disciplines outside the realm of the natural sciences. A number of articles have been published in prominent newspapers and magazines such as the Economist and the New York Times about the existence of a "physics envy" in the social sciences and in particular business schools (Anonymous, 2007; J.L.H.D., 2011; Clarke and Primo, 2012). Far from positive, the "physics envy" is a sign that these disciplines somehow suffer from a sort of inferiority complex, and have a hard time dealing with the complex and embedded nature of the issues they attempt to research while providing the breadth and generalisation qualities often required to gain reputation as an academic. In the context of $\mathrm{SCM}$ research, this raises the question of whether research that is carried out is practically useful for those affected most by the issues investigated, such as practicing managers. Quoted in The Economist (J.L.H.D., 2011), Bent Flyvberg, declares that trying to emulate the physics, 
or natural sciences, paradigm will eventually make the social sciences irrelevant. We further argue that it simply serves to reproduce dominant gendered practices, which are defined around the masculine research ideal type as discussed previously.

The nature of academia requires us to embed ourselves in the field; thus, precluding us from suspending our learned knowledge and determines that much of our thinking is shaped by the field. This both allows us to move the field forward and avoid replication of previous studies but narrows what we may consider as feasible or publishable. Published papers in academia generally subscribe to a certain format, in their structure, content, length and often focus. Forms of writing are themselves constrained by the scientific ideals described above that value rigorous, abstract, a-contextual and law-like accounts (Phillips et al., 2014; Pullen and Rhodes, 2015). Writing is also gendered and by not recognising that, what we accept as normal academic writing is reproducing masculine discourses and ways of doing. We edit our styles to conform and hence marginalise other ways of writing and therefore seeing and understanding. As Rhodes (2015, p. 289) puts it:

A provocation [...] the minds of my generation of organizational theorists are haunted by the spectre of scientific discourse, shoehorned into dry genres, bullied by audit regimes that try to wring the passion out of thought. Without gaiety, the science that calls us has no exuberance, it cannot dance. What are the possibilities for writing about organizations that allows the heart's instincts to be followed, the vast possibilities of expression to be explored and enjoyed?

Often the scope of our studies is also dependent on a number of external factors, e.g., the study may be part of a larger pre-defined study, publishing process or funding requirements, all of which limit what we can - have the right to - explore. The two key metrics of business schools, i.e., the ability to attract funding and to publish in line with ABS/FT50 rankings or the Research Excellence Frameworks are being increasingly described as driving the wrong behaviour (Lambert, 2019). The necessity to ascribe funding bodies' diktat limits us in terms of scope, impact and deliverables. These rules often have a Western-centric focus with little acknowledgement of their potential post-colonial implications (e.g. UK Strategy for the Global Challenges Research Fund - UKRI, 2017). This limits the scope for contextualisation and for re-imagining the field in the first instance. Publishing journal articles also generally involves numerous rounds of editing for "fit". These include our own edits to adhere to the style and structure of the journals we target. Additionally, the trade-off between what we may seek to write and what we feel we should write contributes to self-editing. The review process comprises a third substantial cycle of editing, contributing to the removal of agency of the authors and may limit the contextual information presented as well as discussion of underlying structures. This is eloquently described by Brewis (2018, p. 21) in her research on experiences of peer-review: "When [academics] speak as authors or their proxies, it is characterized as reproducing disciplinary orthodoxy and ethnocentric exclusion, perpetuating disciplinary cliques, creating disorganized papers and constituting excessive interference with authorial privilege".

So, what does this all tell about the SCM researcher as a subject? It gives a sense of the constraints we experience but also reproduce in our practices, whether through the themes that we choose to investigate, the knowledge production practices we follow or the ways in which we report them. The uniformity that pervades our field is a symptom of our failure to engage with a broader diversity of questions and approaches. At the same time, we notice a pattern whereby we position ourselves as unable to address the more complex societal challenges due to their magnitude, dynamism, value-laden and context-dependent nature (Darby et al., 2019). The tendency to solely construct problems that we can help solve, mostly through rationalist approaches, leads to instrumental problematisation, a corporate-driven agenda and a removal of our own agency in addressing these broader challenges. 
There is limited interrogation of why we conduct such research and what constitutes meaningful research in the first place. We seem to have fallen into the "promiscuous crypto conservatism" that Andreski (1972, cited in New, 1997, p. 21) warned us about, supporting the dominant orthodoxy because of our lack of reflexivity. We contend that it is urgent to re-appropriate our own agency as SCM researchers in addressing societal grand challenges (George et al., 2016). If we consider the practical roots of logistics and SCM, then it is worth considering what the role of research may be in contributing to practical wisdom. The term practical wisdom is used here in reference to the concept phronetic research proposed by Flyvbjerg (2001), which in turn comes from phronesis, a term borrowed from Aristotelian philosophy (Flyvbjerg, 2001; Cassell et al., 2009). Phronesis in Flyvberg's sense is about interrogating the direction taken by society, and whether it will lead to a desirable future. The primary purpose of such research is to contribute to the development of praxis and to society's wellbeing. Hence, SCM researchers need to reflect upon what developing and delivering research for SCM actually implies and what constitutes a desirable future for both the field and practice. In line with Heron and Reason (1997), we call for a re-integration of a value dimension in our research whereby as researchers we consider "what is intrinsically worthwhile" (1997), i.e., what constitutes valuable or useful knowledge. The meaning of usefulness here is about Interrogating the choices and directions taken in the research in light of the broader context in which it takes place.

\subsection{The context of SCM research: articulating the challenges}

Our challenge to the accepted norms of the field and our call for a re-embedding of the researchers, as normative agents, into the research practices stems from the recognition of the urgency of the environmental and socio-political context in which we find ourselves as SCM researchers. We cannot remain passive researchers-observers.

There remains a societal reluctance in accepting our creation of the current Anthropocene, an epoch demarcated by mankind's dominant impact on the natural environment over all other forces (Johnson et al., 2014; Crutzen, 2002). We argue that climate breakdown is the key societal grand challenge that management research should engage with (George et al., 2016). While this environmental crisis takes place alongside societal and political concerns, we follow the ecologically dominant model (Montabon et al., 2016) as a guide in our thinking. Key environmental concerns include our continued traversing of planetary boundaries (Steffen et al., 2015), reduced biodiversity (Winn and Pogutz, 2013), water stresses, marine life degradation, food shortages and famine (e.g. UN Sustainable Development Goals). Little progress has been made by G20 countries despite their pledges. The IPCC (2013) has long evidenced the critical state we are in, detailing that we must cut carbon emissions by 45 per cent by 2030, the Climate Council is capturing record breaking heatwaves; yet we still see a tripling of coal power subsidies (Carrington, 2019b), a steady rise in meat consumption (Devlin, 2018), the opening up of the Amazonian rain forest to mining and the active silencing of climate science by Donald Trump (Carrington, 2019a).

Environmental issues of production and consumption are linked by supply networks globally (Carolan, 2004) connecting the Global North with the Global South. SC researchers, amongst others, recognise that value and raw materials are created upstream, as economic value gets added downstream along the logistical journey. Take the illustrative example of vanilla, a commodity that exemplifies the connective abilities and disparities highlighted by luxury food chains. It is the world's second most expensive spice (\$200-400 a kilo) with 80 per cent of global production being located in Madagascar. Yet Madagascan farmers can get as little as $\$ 6$ a kilo and face increasingly difficult and volatile growing conditions and adverse weather conditions where growers facing minimal or non-existent profit margins. The majority of consumers remain largely disconnected from these realities yet will encounter vanilla in many ways through consumption. These examples serve to highlight 
both the environmental pressures of our current way of organising SCs but equally that these are essentially relying on inequitable practices.

Bauman (1991) argued that techno-rational forms of control, as promoted through SCM (see section 1), cause us to limit our ethical concerns to those "near" to us, allowing us to neglect those "far" away, suggesting that bureaucracy acts as a "moral sleeping pill". While economic activity has become socially dispersed, there is limited evidence of social closeness, and much of the literature assumes that the moral agent lives in the affluent Global North and the (potentially) affected stranger in the impoverished Global South, thus allowing those in the Global North the power of decision making as well as the distance to disregard the impact of said decisions, as Bauman (1991, p. 192) suggests "Commitment of immoral acts [...] becomes easier with every inch of social distance".

While the production and the consumption patterns driven by the West are key contributors to climate breakdown, the lived impacts are more severe in the Global South. We see an advent of climate apartheid, "where the rich pay to escape heat and hunger caused by the escalating climate crisis while the rest of the world suffers" (Carrington, 2019a) and where fundamental human rights and democracies are undermined. Equally poverty is both a macro-economic and a micro-economic problem. Poverty in "developing" countries cannot be understood without reference to the global political economy that is controlled by "developed" countries. The exploitative relationship between the "developed" and "developing" countries is a major driver of poverty and hazard for the people of the "developing" countries. The global SCs of multinational companies are often the mechanisms through which this exploitation is organised. The notion of SC practices alleviating poverty, aiding development, contributing to empowerment (McCarthy et al., 2018) must be questioned on the basis that they reproduce post-colonial patterns of exploitation in the form of neo-colonialism (Prasad, 2003).

Furthermore, we cannot ignore the current disenchantment that characterises the present political context and how this has translated into challenges to the establishment (i.e. rise of populist movements globally), and a questioning of the role of experts (i.e. post-truth, fake news [...]). These trends are already shaping institutions, government policies and practices (De Cleen et al., 2018), which will inevitably affect SCs.

Overall, as SCM researchers we must reflect on how our research is shaped by and in turn shapes these broader contextual dynamics. We have a role to play in at our very least we ensure that we are not embedding dominant exploitative practices in our contributions and thus legitimising them further. We call for collective action here taking the view that "even if potential solutions exist, these global problems require coordinated action" (George et al., 2016).

\subsection{Research activism in SCM: resistance and solidarity}

In light of these grand challenges, we can no longer be passers-by. It is time for us to act up, speak out and challenge the status quo. We conceive of this enactment of our human agency as researchers as collective resistance, i.e., "acting otherwise" (Mumby, 2005). We encourage $\mathrm{SCM}$ researchers to become politically engaged through acts of "everyday resistance" (Johansson and Vinthagen, 2016), disrupting consensus and dominant power structures (Rhodes et al., 2018).

For Rhodes et al. (2018), to be an activist refers to the ways that academic work, and academic themselves, can politically intervene into the non-academic world "out there" with a "view of changing it". We go a step further in our conception of activism in recognising the need to also intervene in our academic field for change to take place through a disruption of the accepted world-order. In this sense, we align with Rancière's view of politics as dissensus, contesting the policing of research. Policing refers to the upholding of the dominant conditions of our field that control what constitutes acceptable, legitimate research as discussed earlier. Being a researcher activist is about becoming "aware of our 
role and our position in social reproduction and social change" (Contu, 2018, p. 285). Holding ourselves to account is a facet of intellectual activism: "it includes our teaching, our service and admin work re-orienting them towards a specific notion of social change, one that is directly conjugated with social, economic and epistemic justice claims and issues" (Contu, 2018, p. 284).

How can we enact this activism in SCM? We see this happening at three levels: in relation to the grand challenges, to the norms of our field and to ourselves. In the rest of this section, we articulate what we see as fruitful avenues at each of these levels to support this.

\subsection{Grand challenges}

We, the researcher community, know about climate breakdown (Steffen et al., 2015; George et al., 2016; Stone, 1972; Carson, 2002; IPCC, 2013), about ecocide (Hamilton, 2016; Wijdekop, 2016) and for more than three decades that more sustainable pathways are vital (World Commission on Environment and Development, 1987). The public is also increasingly conscious of this challenge (Nyberg and Wright, 2016). Equally, we know that SCs can play a central role in transitioning to more socially equitable societies (Mohrman and Worley, 2010). Yet, what we fail to understand is why we are not reacting appropriately to this emergency, why we persevere with climate capitalism (Böhm et al., 2012), why we respond with incremental advances, tokenism, "greening practices" and aspirations of technological salvation (Asafu-Adjaye et al., 2015; Montabon et al., 2016). Inherent in this is the apparent normalisation of these concerns (Wright and Nyberg, 2017) and our inability to accept we can no longer pursue a growth paradigm that is "liquidating our natural capital" (Daly, 1996).

The desire to narrow the focus of our research to particular contextual concerns, often for the valued process of theorising (Roberts et al., 1978 in Bamberger, 2008) as discussed previously, can limit the utility of our research and lead to its decontextualisation. The research agenda is often driven by the lead firm or dominant actor in a supply chain, who direct the research in an instrumental manner to address and include issues (e.g. social and environmental regulation, structural limitations, resource access, training and expertise, services) that are of their concern over urgent societal challenges. Thus the relevance of research in the SCM field is being questioned in terms of its value for practitioners (Lambert, 2019) and society (George et al., 2016).

In the SCM field, we call for conceptual innovation and a shift of focus towards the visions of alternative voices and perspectives, like those of suppliers, in order to find new ways to address social and environmental challenges. We therefore propose an alternative to the dominant view of SSCM as solely determined by the actions of large corporations. This perspective fully embraces power as a central concept in the production of knowledge on how to advance towards more sustainable production and consumption networks. Power here is taken broadly as productive and emancipating rather than solely restrictive and repressive (Caldwell, 2007; Foucault, 1980) and serves to conceptualise sustainability as collective social change (Aguilera et al., 2007; Hargrave and Van de Ven, 2006). In this conceptual and empirical shift towards facilitating agency-building for traditionally marginalised stakeholders, we can radically challenge conventional perspectives on how sustainable development should be addressed in SCs.

This paves the way for establishing a new "critical SCM" paradigm and a re-imagining that could move us towards creating more socially equitable and environmentally resilient supply chains. We see the potential of this "critical SCM" paradigm to contribute to "critical performativity", as the ongoing process of enacting critical theory. This would allow surfacing in our research management practices and insights that challenge the social injustice and environmental destructiveness of global capitalism (Adler et al., 2007; Kazmi et al., 2016; Spicer et al., 2009). This alternative paradigm would join critical management scholarship, in offering a critical theory lens to "engage in concerted efforts to reveal the 
problematic deployments of" sustainability by dominant players (i.e. large focal firms in SCs) (Prasad and Mills, 2010, p. 231). We ask for solidarity rather than empathy or any form of instrumental empowerment bestowed by big corporations (McCarthy et al., 2018). We ask to shed light not only on the issues but to reapportion the accountability to those driving the production and consumption patterns that have led us to this state.

Increasing the diversity of our SCM paradigms will inevitably lead to a diversity of approaches, foci, methods of interrogation (Matthews et al., 2016) and ultimately to the disruption of the dominant norms of the field.

\subsection{Norms of our field}

In considering how we can collectively enact resistance in our field, we focus on activism in those aspects of the field for which we have responsibility as a group of scholars. Collective action sees the formation of groups of individuals drawn together around values and shared ideas, common needs or collective gain (Teegen et al., 2004). The goal is to achieve a common aim that would not be realized through acting alone. This can include changing discourse, political and social realities (Pharr, 2003; Habermas, 1989 in Teegen et al., 2004).

We echo Darby et al. (2019) call in this journal on the need to use more varied methodological approaches as a mechanism to shift from the predominantly positivistic paradigm of the SCM field. There is a tendency towards modes of knowledge production where theory and practice are taken to exist separately. A move towards more critical engagement should see further applicability of the knowledge produced to real world knowledge and a contextualisation of this knowledge (Gibbons et al., 1994). Paradigmatic diversity and new ways of organising will allow for the collective surfacing of new questions, theorising and theory elaboration with the focus on addressing the grand challenges (Fugate et al., 2019). We can apply and extend theories that move beyond the economic to the socio-political, such as global production network theory (Yeung and Coe, 2015). Feminist theory and associated research approaches would offer an alternative to dominant approaches that have so far valued rationality, control, codification and masculinity, and allow for the re-valuing of questions of social justice, affect, care, lived experiences and compassion (Pullen and Rhodes, 2014).

In line with the last point, as we discussed earlier, language is a powerful tool in shaping discourse and re-enforcing dominant ideologies (Fairclough, 2003), but also it is a tool that we can use to try to bring in different perspectives (Gibson-Graham, 2006) and encourage a transformative redefinition of discourses (Alvesson and Spicer, 2012). Hence, we highlight the potential of feminine writing in challenging current dominant masculine discourses in our field. This would allow for different writing styles that incorporate a multitude of voices (inclusivity) so that these voices are given equitable space (fairness) while doing justice to the context (over categorisation) (Phillips et al., 2014; Pullen and Rhodes, 2015; Vachhani, 2015). We imagine that allowing for such alternative forms of writing in the field of SCM would translate in diverse forms of telling the story of SCs and therefore ways of imagining SCs. These alternative forms would include various approaches to analysing and representing SC phenomena, such as for example reflexive and narrative accounts that provide "windows into the emotional and symbolic lives of organisations" (Phillips et al., 2014, p. 319). McCarthy's (2017) article on her work with women farmers in cocoa supply chains provides a valuable example of how such approaches can be fruitfully applied.

In order to allow for different forms of writing, we also need to challenge the conventions of our field with regards to publishing. A more liberal approach in the editorial and review process can be extremely illuminating and beneficial. In other fields, we see more diverse styles being promoted by recognised journals, e.g., "Speak Out" and "Act Up" submission types in the journal organisation. This very piece is the result of being given such opportunity in our field and we would hope that this would be built upon. We can encourage each other 
through review processes by being less prescriptive in what an article should look like. What if we read each article not from our own lens but with empathy with the authors' perspective? We have experienced such positive approach to the review process when we were invited to be reflexive (rather than to add specific parts or references to the paper).

Our role as academics and disseminators of knowledge extends to our position as educators, where sharing our knowledge or challenging dominant discourses can be much more immediate in its impact. Currently, business schools tend to teach a neo-liberal agenda, the marketization of society and transmit corporate ideologies (Fleming and Oswick, 2014). We call for the embedding of different paradigms, ways of knowing and organising, or at the very least the disclosure of perspectives and counter perspectives. This would result in differing, alternative lenses in our teaching. For instance, can we consider teaching sufficiency, equitability, degrowth, and alternative forms of organising as part of our SC courses? If we are to embed the grand challenges in our teaching, we need to recognise that they are normative issues and educating to address them is therefore a value-laden endeavour. We need to embed explicit discussion of values, through reflexive practice, with our students. This implies that as educators, we also need to practice reflexivity and be mindful of our position.

\subsection{Individual level}

At the individual level, we argue that SCM researchers should consider their positionality through an engagement with the notion of reflexivity. A common theme in human geography (Jackson, 1993; Hopkins, 2007), feminist studies (England, 1994) and critical management studies (Brewis and Wray-Bliss, 2008), positionality is a less explored concept in OM/SCM. Recognising your (multiple) positionality/positionalities allows for the exploration of the "politics of position" (Smith, 1993 in Hopkins, 2007) and the influence this may have throughout the research process. Positionality should be considered part of the research process, i.e., not only do we act but we are also acted on (Deutsch, 2004). Therefore we must examine our positionality reflexively (Rose, 1997). As researchers, and particularly in relation to qualitative research, we must acknowledge the limits of objectivity, forming an awareness of our own "subjective experience in relation to that of [our] participants" (Deutsch, 2004).

Reflexivity allows us to consider the values of the research for the researcher, the participants, the field as well as the broader context. It allows us to find strategies to question and strive to understand our complex roles in relation to others (Bolton, 2010). Traditional research approaches tend to resonate with the concept of third-person research (Bradbury and Lichtenstein, 2000) in the more objectivity-seeking research dissemination. We argue that it is not possible, (or even desirable) to detach ourselves as researchers from what we are observing (Easterby-Smith and Malina, 1999). Reflexivity is personal and contextual, and takes place cyclically throughout the research process (Pedersen and Olesen, 2008; Näslund et al., 2010). It is also predicated on its connection to "purpose and agenda" without which reflexivity has little utility (Kobayashi, 2003). Reflexivity allows us to consider the limits of existing knowledge, it can move us to new methods of enquiry, learning and knowing in order to tackle the grand challenges. We suggest that it is productive and informative to reflect on and disclose the underlying philosophical positioning of the researcher. It can be challenging to consider the multiplicity of perspectives, but engagement with reflexive practice can lead to the surfacing of the realisation of value tensions that exist between the research and our own espoused values (Deutsch, 2004). It is also understood here that the researcher has an influence on the research and that the research influences the researcher (Marshall and Reason, 2007; Reason, 2006).

In our efforts to be inclusive we must always consider our positionality, as well as issues of representation and access, and be mindful of appropriating the voices of "others" (England, 1994; Sultana, 2007). Even in our awareness of these power relations, they are not removed so "we must accept responsibility for the research" (England, 1994). Reflexivity and positionality 
can aid our awareness; ethics, continuous consent and care throughout the process can help limit potential side/detrimental effects. However, it is key to constantly consider whether we should be engaging in the research in the first place (England, 1994).

As alternatives to the rationalist methods, we can draw on feminist and post-modernist approaches to treat people as people, engage in dialogue and seek to shift "power over to the researched". We also can include the self in the research process, acknowledging that we come with our own sensibilities, previous experiences and biases - not as "dematerialized, disembodied entities" (England, 1994). We consider that collaborative methods allow for the research to be conducted "with" and not "about" people (Sultana, 2007). Considering the political-temporal aspects of the research and presenting the context are critical so that in our interpretations we can consider the reproduction of certain issues and the potential silencing of other voices or concerns (Sultana, 2007).

Ultimately, we echo Peattie in seeing potential for us as researchers "to be visionaries as well as heretics. [...] Instead of a conventional career path as paradigm takers, [we] need to be willing to try to be paradigm breakers and makers" (Peattie, 2011, pp. 31-32).

\section{Concluding thoughts}

Breaking away from conventions and accepted norms is difficult. However, in light of the grand challenges we have highlighted, not doing anything is ultimately contributing to their worsening. We recognise that activism is potentially risky (Rhodes et al., 2018) and therefore we seek to create a safe space for dialogue and action and advocate solidarity in the discipline (as opposed to competition) as a mechanism to support one another.

\section{References}

Adler, P., Forbes, L. and Willmott, H. (2007), “Critical management studies”, Academy of Management Annals, Vol. 1 No. 1, pp. 119-179.

Aguilera, R.V., Rupp, D.E., Williams, C.A. and Ganapathi, J. (2007), "Putting the S back in corporate social responsibility: a multilevel theory of social change in organizations", Academy of Management Review, Vol. 32 No. 3, pp. 836-863.

Aktouf, O. (1992), "Management and theories of organizations in the 1990s: toward a critical radical humanism?", Academy of Management Review, Vol. 17 No. 3, pp. 407-431.

Al-Amoudi, I., Edwards, T., O'Mahoney, H. and O'Mahoney, J. (2017), "Introduction: de/humanization and critical realism", Journal of Critical Realism, Vol. 16 No. 4, pp. 349-352.

Alvesson, M. and Spicer, A. (2012), "Critical leadership studies: the case for critical performativity", Human Relations, Vol. 65 No. 3, pp. 367-390.

Amui, L.B.L., Jabbour, C.J.C., de Sousa Jabbour, A.B.L. and Kannan, D. (2017), "Sustainability as a dynamic organizational capability: a systematic review and a future agenda toward a sustainable transition", Journal of Cleaner Production, Vol. 142, pp. 308-322.

Andreski, S. (1972), Social Science as Sorcery, Andre Deutsch, London.

Anonymous (2007), "Practically irrelevant?", The Economist, London, 28 August, available at: www. economist.com/node/9707498

Asafu-Adjaye, J., Blomquist, L., Brand, S., Brook, B.W., DeFries, R., Ellis, E., Foreman, C., Keith, D., Lewis, M., Lynas, M. and Nordhaus, T. (2015), "An ecomodernist manifesto".

Bamberger, P. (2008), "From the editors beyond contextualization: using context theories to narrow the micro-macro gap in management research", Academy of Management Journal, Vol. 51 No. 5, pp. 839-846.

Barratt, M., Choi, T.Y. and Li, M. (2011), "Qualitative case studies in operations management: trends, research outcomes, and future research implications", Journal of Operations Management, Vol. 29 No. 4, pp. 329-342. 
Bauman, Z. (1991), "The social manipulation of morality: moralizing actors, adiaphorizing action", Theory, Culture \& Society, Vol. 8 No. 1, pp. 137-151.

Ben-Daya, M., Hassini, E. and Bahroun, Z. (2019), "Internet of things and supply chain management: a literature review", International Journal of Production Research, Vol. 57 Nos 15-16, pp. 4719-4742.

Böhm, S., Misoczky, M.C. and Moog, S. (2012), "Greening capitalism? A Marxist critique of carbon markets”, Organization Studies, Vol. 33 No. 11, pp. 1617-1638.

Bolton, G. (2010), Reflective Practice, Sage, Los Angeles, CA.

Bothello, J. and Roulet, T.J. (2018), "The imposter syndrome, or the mis-representation of self in academic life", Journal of Management Studies, Vol. 56 No. 4, pp. 854-861.

Boyer, K.K. and Swink, M.L. (2008), "Empirical elephants - why multiple methods are essential to quality research in operations and supply chain management”, Journal of Operations Management, Vol. 26 No. 3, pp. 338-344.

Bradbury, H. and Lichtenstein, B. (2000), "Relationality in organizational research: exploring the space between”, Organization Science, Vol. 11, pp. 551-564.

Brewis, J. (2018), "On interference, collegiality and co-authorship: peer review of journal articles in management and organization studies", Organization, Vol. 25 No. 1, pp. 21-41.

Brewis, J. and Wray-Bliss, E. (2008), "Re-searching ethics: towards a more reflexive critical management studies”, Organization Studies, Vol. 29 No. 12, pp. 1521-1540.

Burgess, K., Singh, P.J. and Koroglu, R. (2006), "Supply chain management: a structured literature review and implications for future research", International Journal of Operations \& Production Management, Vol. 26 No. 7, pp. 703-729.

Caldwell, R. (2007), “Agency and change: re-evaluating Foucault's legacy”, Organization, Vol. 14 No. 6, pp. 769-791.

Carolan, M.S. (2004), "Ecological modernization theory: what about consumption?", Society and Natural Resources, Vol. 17 No. 3, pp. 247-260.

Carrington, D. (2019a), “'Climate apartheid': UN expert says human rights may not survive”, available at: www.theguardian.com/environment/2019/jun/25/climate-apartheid-united-nations-expert-sayshuman-rights-may-not-survive-crisis (accessed 25 June 2019).

Carrington, D. (2019b), "G20 countries triple coal power subsidies despite climate crisis”, available at: www.theguardian.com/environment/2019/jun/25/g20-nations-triple-coal-power-subsidiesclimate-crisis (accessed 26 June 2019).

Carson, R. (2002), Silent Spring, Houghton Mifflin Harcourt, CT.

Carter, C., Sanders, N. and Dong, Y. (2008), "Paradigms, revolutions, and tipping points: the need for using multiple methodologies within the field of supply chain management", Journal of Operations Management, Vol. 26 No. 6, pp. 693-696.

Cassell, C., Bishop, V., Symon, G., Johnson, P. and Buehring, A. (2009), "Learning to be a qualitative management researcher", Management Learning, Vol. 40 No. 5, pp. 513-533.

Cerchione, R. and Esposito, E. (2016), "A systematic review of supply chain knowledge management research: state of the art and research opportunities", International Journal of Production Economics, Vol. 182, pp. 276-292.

Christensen, L.T., Moring, M. and Thyssen, O. (2013), “CSR as aspirational talk”, Organization, Vol. 20 No. 3, pp. 372-393.

Clarke, K.A. and Primo, D.M. (2012), "Overcoming 'physics envy', The New York Times, Sunday Review, NY, available at: www.nytimes.com/2012/04/01/opinion/sunday/the-social-sciencesphysics-envy.html

Contu, A. (2018), “'... The point is to change it'- Yes, but in what direction and how? Intellectual activism as a way of 'walking the talk' of critical work in business schools", Organization, Vol. 25 No. 2, pp. 282-293.

Crutzen, P.J. (2002), “The 'anthropocene'”, Journal de Physique IV (Proceedings), Vol. 12 No. 10, pp. 1-5. 
Cummings, S. and Bridgman, T. (2011), "The relevant past: why the history of management should be critical for our future", Academy of Management Learning \& Education, Vol. 10 No. 1, pp. 77-93.

Daly, H.E. (1996), Beyond Growth: The Economics of Sustainable Development, Beacon Press, Boston, MA.

Darby, J.L., Fugate, B.S. and Murray, J.B. (2019), "Interpretive research: a complementary approach to seeking knowledge in supply chain management", International Journal of Logistics Management, Vol. 30 No. 2, pp. 395-413.

De Cleen, B., Glynos, J. and Mondon, A. (2018), "Critical research on populism: nine rules of engagement", Organization, Vol. 25 No. 5, pp. 649-661.

Deutsch, N.L. (2004), "Positionality and the pen: reflections on the process of becoming a feminist researcher and writer", Qualitative Inquiry, Vol. 10 No. 6, pp. 885-902.

Devlin, H. (2018), "Rising global meat consumption 'will devastate environment', available at: www. theguardian.com/environment/2018/jul/19/rising-global-meat-consumption-will-devastateenvironment (accessed 18 July 2018).

Durach, C.F., Kembro, J. and Wieland, A. (2017), "A new paradigm for systematic literature reviews in supply chain management”, Journal of Supply Chain Management, Vol. 53 No. 4, pp. 67-85.

Durach, C.F., Wieland, A. and Machuca, J.A. (2015), "Antecedents and dimensions of supply chain robustness: a systematic literature review", International Journal of Physical Distribution \& Logistics Management, Vol. 45 Nos 1/2, pp. 118-137.

Easterby-Smith, M. and Malina, D. (1999), "Cross-cultural collaborative research: toward reflexivity”, Academy of Management Journal, Vol. 42 No. 1, pp. 76-86.

Eisenhardt, K.M. (1991), "Better stories and better constructs: the case for rigor and comparative logic", Academy of Management Review, Vol. 16 No. 3, pp. 620-627.

Ellram, L.M. and Cooper, M.C. (2014), "Supply chain management: it's all about the journey, not the destination”, Journal of Supply Chain Management, Vol. 50 No. 1, pp. 8-20.

England, K.V. (1994), “Getting personal: reflexivity, positionality, and feminist research", The Professional Geographer, Vol. 46 No. 1, pp. 80-89.

Fairclough, N. (2003), Analysing Discourse: Textual Analysis for Social Research, Psychology Press, London.

Fang, C. and Zhang, J. (2018), "Performance of green supply chain management: a systematic review and meta analysis", Journal of Cleaner Production, Vol. 183, pp. 1064-1081.

Fleming, P. and Oswick, C. (2014), "Educating consent? A conversation with Noam Chomsky on the university and business school education”, Organization, Vol. 21 No. 4, pp. 568-578.

Flyvbjerg, B. (2001), Making Social Science Matter: Why Social Inquiry Fails and How it can Succeed Again, Cambridge University Press, Cambridge.

Foucault, M. (1980), Power/Knowledge, Pantheon, New York, NY.

Fournier, V. and Grey, C. (1999), "Too much, too little and too often: a critique of du Gay's analysis of enterprise", Organization, Vol. 6 No. 1, pp. 107-128.

Fugate, B., Pagell, M. and Flynn, B. (2019), "From the editors: introduction to the emerging discourse incubator on the topic of research at the intersection of supply chain management and public policy and government regulation”, Journal of Supply Chain Management, Vol. 55 No. 2, pp. 3-5.

Gelsomino, L.M., Mangiaracina, R., Perego, A. and Tumino, A. (2016), "Supply chain finance: a literature review", International Journal of Physical Distribution \& Logistics Management, Vol. 46 No. 4, pp. 348-366.

George, G., Howard-Grenville, J., Joshi, A. and Tihanyi, L. (2016), "Understanding and tackling societal grand challenges through management research", Academy of Management Journal, Vol. 59 No. 6, pp. 1880-1895.

Gibbons, M., Limoges, C., Nowotny, H., Schwartzman, S., Scott, P. and Trow, M. (1994), The New Production of Knowledge: The Dynamics of Science and Research in Contemporary Societies, Sage, London. 
Gibson-Graham, J.K. (2006), A Postcapitalist Politics, University of Minnesota Press, Minneapolis, MN.

Govindan, K. and Bouzon, M. (2018), "From a literature review to a multi-perspective framework for reverse logistics barriers and drivers", Journal of Cleaner Production, Vol. 187, pp. 318-337.

Habermas, I. (1989), Between Facts and Norms: Contributions to a Discourse Theory of Law and Democracy (translated by W. Rehg), MIT Press, Cambridge, MA.

Hamilton, C. (2016), "The theodicy of the 'good anthropocene'”, Environmental Humanities, Vol. 7 No. 1, pp. 233-238.

Hargrave, T.J. and Van de Ven, A.H. (2006), "A collective action model of institutional innovation", Academy of Management Review, Vol. 31 No. 4, pp. 864-888.

Heron, J. and Reason, P. (1997), “A participatory inquiry paradigm”, Qualitative Inquiry, Vol. 3 No. 3, pp. 274-296.

Hopkins, P.E. (2007), "Positionalities and knowledge: negotiating ethics in practice", ACME: An International Journal for Critical Geographies, Vol. 6 No. 3, pp. 386-394.

IPCC (2013), “Climate change 2013: the physical science basis”, Working group I contribution to the fifth assessment report of the intergovernmental panel on climate change, Cambridge University Press, Cambridge.

Jackson, P. (1993), “Changing ourselves: a geography of position”, in Johnston, R.J. (Ed.), The Challenge for Geography, A Changing World: A Changing Discipline, Blackwell Publishers, Oxford, pp. 198-214.

J.L.H.D. (2011), "Business-school research: the physics-envy problem", The Economist, Atlanta, available at: www.economist.com/whichmba/business-school-research-physics-envy-problem

Johansson, A. and Vinthagen, S. (2016), "Dimensions of everyday resistance: an analytical framework", Critical Sociology, Vol. 42 No. 3, pp. 417-435.

Johnson, E., Morehouse, H., Dalby, S., Lehman, J., Nelson, S., Rowan, R., Wakefield, S. and Yusoff, K. (2014), "After the Anthropocene: politics and geographic inquiry for a new epoch", Progress in Human Geography, Vol. 38 No. 3, pp. 439-456.

Jones, T.C. and Riley, D.W. (1985), "Using inventory for competitive advantage through supply chain management”, International Journal of Physical Distribution \& Materials Management, Vol. 15 No. 5, pp. 16-26.

Kaufmann, L. and Denk, N. (2011), "How to demonstrate rigor when presenting grounded theory research in the supply chain management literature", Journal of Supply Chain Management, Vol. 47 No. 4, pp. 64-72.

Kazmi, B.A., Leca, B. and Naccache, P. (2016), "Is corporate social responsibility a new spirit of capitalism?”, Organization, Vol. 23 No. 5, pp. 742-762.

Kobayashi, A. (2003), "GPC ten years on: is self-reflexivity enough?”, Gender, Place and Culture, Vol. 10 No. 4, pp. 345-349.

Lambert, D.M. (2019), “Rediscovering relevance”, The International Journal of Logistics Management, Vol. 30 No. 2, pp. 382-394.

Lewin, K. (1951), Field Theory in Social Science: Selected Theoretical Papers, Harper \& Row, New York, NY.

McCarthy, L. (2017), "Empowering women through corporate social responsibility: a feminist Foucauldian critique", Business Ethics Quarterly, Vol. 27 No. 4, pp. 603-631.

McCarthy, L., Touboulic, A. and Matthews, L. (2018), "Voiceless but empowered farmers in corporate supply chains: contradictory imagery and instrumental approach to empowerment", Organization, Vol. 25 No. 5, pp. 609-635.

Maestrini, V., Luzzini, D., Maccarrone, P. and Caniato, F. (2017), "Supply chain performance measurement systems: a systematic review and research agenda", International Journal of Production Economics, Vol. 183, Part A, pp. 299-315. 
Marshall, J. and Reason, P. (2007), "Quality in research as 'taking an attitude of inquiry', Management Research News, Vol. 30 No. 5, pp. 368-380.

Matthews, L., Power, D., Touboulic, A. and Marques, L. (2016), "Building bridges: towards alternative theory of sustainable supply chain management", Journal of Supply Chain Management, Vol. 52 No. 1, pp. 82-94.

Mentzer, J.T., DeWitt, W., Keebler, J.S., Min, S., Nix, N.W., Smith, C.D. and Zacharia, Z.G. (2001), "Defining supply chain management", Journal of Business Logistics, Vol. 22 No. 2, pp. 1-25.

Mickey 3D (2016), Respire Moumkine Music, Licence Exclusive Parlophone/Warner Music France, a Warner Music Group Company, available at: www.youtube.com/watch?v=Iwb6u1Jo1Mc (accessed 27 June 2019).

Mohrman, S.A. and Worley, C.G. (2010), "The organizational sustainability journey: introduction to the special issue”, Organizational Dynamics, Vol. 39 No. 4, pp. 289-294.

Monczka, R.M., Petersen, K.J., Handfield, R.B. and Ragatz, G.L. (1998), "Success factors in strategic supplier alliances: the buying company perspective”, Decision Sciences, Vol. 29 No. 3, pp. 553-577.

Montabon, F., Pagell, M. and Wu, Z. (2016), "Making sustainability sustainable", Journal of Supply Chain Management, Vol. 52 No. 2, pp. 11-27.

Mumby, D.K. (2005), "Theorizing resistance in organization studies: a dialectical approach", Management Communication Quarterly, Vol. 19 No. 1, pp. 19-44.

Näslund, D. (2002), "Logistics needs qualitative research - especially action research", International Journal of Physical Distribution \& Logistics Management, Vol. 5, pp. 321-338.

Näslund, D., Kale, R. and Paulraj, A. (2010), "Action research in supply chain management: a framework for relevant and rigorous research", Journal of Business Logistics, Vol. 31 No. 2, pp. 331-355.

New, S.J. (1997), “The scope of supply chain management research", Supply Chain Management: An International Journal, Vol. 2 No. 1, pp. 15-22.

Nyberg, D. and Wright, C. (2016), "Performative and political: corporate constructions of climate change risk”, Organization, Vol. 23 No. 5, pp. 617-638.

Pagell, M. and Shevchenko, A. (2014), "Why research in sustainable supply chain management should have no future", Journal of Supply Chain Management, Vol. 50 No. 1, pp. 44-55.

Peattie, K. (2011), "Sustainability research: an introduction", in Franklin, A. and Blyton, P. (Eds), Researching Sustainability: A Guide to Social Science Methods, Practice and Engagement, pp. 3-16.

Pedersen, C.H. and Olesen, B.R. (2008), "What knowledge-which relationships? Sharing dilemmas of an action researcher", International Journal of Action Research, Vol. 4 No. 3, pp. 254-290.

Pharr, S.J. (2003), "Preface", in Schwartz, F.J. and Pharr, S.J. (Eds), The State of Civil Society in Japan, Cambridge University Press, Cambridge, p. xiii.

Phillips, M., Pullen, A. and Rhodes, C. (2014), "Writing organization as gendered practice: interrupting the libidinal economy”, Organization Studies, Vol. 35 No. 3, pp. 313-333.

Phillips, N. and Hardy, C. (2002), Discourse Analysis: Investigating Processes of Social Construction, Sage, Thousand Oaks, CA.

Prasad, A. (2003), Postcolonial Theory and Organizational Analysis: A Critical Engagement, Springer, New York, NY.

Prasad, A. and Mills, A.J. (2010), "Critical management studies and business ethics: a synthesis and three research trajectories for the coming decade", Journal of Business Ethics, Vol. 94 No. 2, pp. 227-237.

Pullen, A. and Rhodes, C. (2014), "Corporeal ethics and the politics of resistance in organizations", Organization, Vol. 21 No. 6, pp. 782-796.

Pullen, A. and Rhodes, C. (2015), "Ethics, embodiment and organizations", Organization, Vol. 22 No. 2, pp. 159-165. 
Quarshie, A.M., Salmi, A. and Leuschner, R. (2016), "Sustainability and corporate social responsibility in supply chains: the state of research in supply chain management and business ethics journals", Journal of Purchasing and Supply Management, Vol. 22, pp. 82-97.

Reason, P. (2006), "Choice and quality in action research practice", Journal of Management Inquiry, Vol. 15 No. 2, pp. 187-206.

Rhodes, C. (2015), "Writing organization/romancing fictocriticism”, Culture and Organization, Vol. 21 No. 4, pp. 289-303.

Rhodes, C., Wright, C. and Pullen, A. (2018), "Changing the world? The politics of activism and impact in the neoliberal university", Organization, Vol. 25 No. 1, pp. 139-147.

Roberts, K.H., Hulin, C.L. and Rousseau, D.M. (1978), Developing an Interdisciplinary Science of Organizations, Jossey-Bass, San Francisco, CA.

Rose, G. (1997), "Situating knowledge: positionality, reflexivities and other tactics", Progress in Human Geography, Vol. 21 No. 3, pp. 305-320.

Seuring, S. and Müller, M. (2008), "From a literature review to a conceptual framework for sustainable supply chain management", Journal of Cleaner Production, Vol. 16 No. 15, pp. 1699-1710.

Shah, S.K. and Corley, K.G. (2006), "Building better theory by bridging the quantitative-qualitative divide", Journal of Management Studies, Vol. 43 No. 8, pp. 1821-1835.

Smith, S.J. (1993), "Bounding the borders: claiming space and making place in rural Scotland", Transactions of the Institute of British Geographers, pp. 291-308.

Spicer, A., Alvesson, M. and Kärreman, D. (2009), "Critical performativity: the unfinished business of critical management studies", Human Relations, Vol. 62 No. 4, pp. 537-560.

Steffen, W., Richardson, K., Rockström, J., Cornell, S.E., Fetzer, I., Bennett, E.M., Biggs, R., Carpenter, S.R., De Vries, W., De Wit, C.A. and Folke, C. (2015), "Planetary boundaries: guiding human development on a changing planet", Science, Vol. 347 No. 6223, pp. 736-747.

Stone, C. (1972), "Do trees have standing", Southern California Law Review, Vol. 45, pp. 450-501.

Sultana, F. (2007), "Reflexivity, positionality and participatory ethics: negotiating fieldwork dilemmas in international research", ACME: An International E-journal for Critical Geographies, Vol. 6 No. 3, pp. 374-385.

Taticchi, P., Garengo, P., Nudurupati, S.S., Tonelli, F. and Pasqualino, R. (2015), “A review of decisionsupport tools and performance measurement and sustainable supply chain management", International Journal of Production Research, Vol. 53 No. 21, pp. 6473-6494.

Teegen, H., Doh, J.P. and Vachani, S. (2004), "The importance of Nongovernmental Organizations (NGOs) in global governance and value creation: an international business research agenda", Journal of International Business Studies, Vol. 35 No. 6, pp. 463-483.

Touboulic, A. and Walker, H. (2015), "Theories in sustainable supply chain management: a structured literature review", International Journal of Physical Distribution \& Logistics Management, Vol. 45 Nos 1/2, pp. 16-42.

Touboulic, A. and Walker, H. (2016), "A relational, transformative and engaged approach to sustainable supply chain management: the potential of action research", Human Relations, Vol. 69 No. 2, pp. 301-343.

Towers, N. and Chen, R. (2008), "Employing the participative paradigm as a valid empirical approach to gaining a greater understanding of contemporary supply chain and distribution management issues”, International Journal of Retail \& Distribution Management, Vol. 36 No. 8, pp. 627-637.

UKRI (2017), "UK strategy for the global challenges research fund", available at: www.ukri.org/ research/global-challenges-research-fund/

Vachhani, S.J. (2015), "Organizing love - thoughts on the transformative and activist potential of feminine writing”, Gender, Work \& Organization, Vol. 22 No. 2, pp. 148-162.

Voss, C., Tsikriktsis, N. and Frohlich, M. (2002), "Case research in operations management", International Journal of Operations \& Production Management, Vol. 22 No. 2, pp. 195-219. 
Wang, G., Gunasekaran, A., Ngai, E.W. and Papadopoulos, T. (2016), "Big data analytics in logistics and supply chain management: certain investigations for research and applications", International Journal of Production Economics, Vol. 176, pp. 98-110.

Wijdekop, F. (2016), “Against ecocide: legal protection for earth”, Great Transition Initiative: Towards a Transformative Vision and Praxis, pp. 1-7.

Winn, M.I. and Pogutz, S. (2013), "Business, ecosystems, and biodiversity: new horizons for management research", Organization \& Environment, Vol. 26 No. 2, pp. 203-229.

Wong, C.Y., Wong, C.W. and Boon-Itt, S. (2015), "Integrating environmental management into supply chains: a systematic literature review and theoretical framework", International Journal of Physical Distribution \& Logistics Management, Vol. 45 Nos 1/2, pp. 43-68.

World Commission on Environment and Development (1987), "Our common future", The Brundtland report, Oxford University Press, Oxford.

Wright, C. and Nyberg, D. (2017), "An inconvenient truth: how organizations translate climate change into business as usual", Academy of Management Journal, Vol. 60 No. 5, pp. 1633-1661.

Wu, L., Yue, X., Jin, A. and Yen, D.C. (2016), "Smart supply chain management: a review and implications for future research", The International Journal of Logistics Management, Vol. 27 No. 2, pp. 395-417.

Yeung, H.W.C. and Coe, N.M. (2015), "Toward a dynamic theory of global production networks", Economic Geography, Vol. 91 No. 1, pp. 29-58.

\section{Further reading}

Casal, P. (2007), "Why sufficiency is not enough", Ethics, Vol. 117 No. 2, pp. 296-326.

Hodal, K. (2016), "Nestlé admits slave labour risk on Brazil coffee plantations", available at: www. theguardian.com/global-development/2016/mar/02/nestle-admits-slave-labour-risk-on-brazilcoffee-plantations (accessed 2 March 2016).

Johnson, C.N., Balmford, A., Brook, B.W., Buettel, J.C., Galetti, M., Guangchun, L. and Wilmshurst, J.M. (2017), "Biodiversity losses and conservation responses in the anthropocene", Science, Vol. 356 No. 6335, pp. 270-275.

Latouche, S. (2009), Farewell to Growth, Polity Press, Cambridge.

Rancière, J. (2010), Dissensus: On Politics and Aesthetics, Bloomsbury, London.

Reedy, P.C. and King, D.R. (2019), "Critical performativity in the field: methodological principles for activist ethnographers”, Organizational Research Methods, Vol. 22 No. 2, pp. 564-589.

\section{Corresponding author}

Lucy McCarthy can be contacted at: L.McCarthy@qub.ac.uk

For instructions on how to order reprints of this article, please visit our website: 